\title{
Synthesis of Alphavirus-Specified RNA
}

\author{
HENRY BRZESKI AND S. IAN T. KENNEDY†* \\ Department of Biological Sciences, University of Warwick, Coventry CV4 7AL, England
}

Received for publication 30 September 1977

\begin{abstract}
UV irradiation of chicken fibroblasts infected with Semliki Forest or Sindbis virus has been used to investigate the mechanism of synthesis of $42 \mathrm{~S}$ and $26 \mathrm{~S}$ RNA, the major plus-strand virus-specified RNAs formed during the multiplication of standard virus particles. From an analysis of the kinetics of UV inactivation of the synthesis of these two RNAs, we conclude (i) that 26S RNA is formed by internal transcriptive initiation from a point about two-thirds of the way from the $3^{\prime}$ end of the $42 \mathrm{~S}$ negative-strand template; (ii) that there exists a population of plus-strand synthesizing complexes whose members are each capable of synthesizing both $42 \mathrm{~S}$ and 26S RNA; and (iii) that, on a time-averaged basis, each complex in wild-type virus-infected cells contains one virus polymerase mediating 42S RNA synthesis and three mediating 26S RNA synthesis. The RNA phenotypes of $15 \mathrm{RNA}^{-} t s$ mutants of Sindbis virus have been examined after temperature shift to the restrictive temperature. Under these conditions, cells infected with three mutants, N2, N7, and E268, synthesized four to six times as much 42S RNA (relative to 26S RNA) as wild-type virus-infected cells. These studies were extended by examining, in detail, the RNA and polypeptide phenotypes of mutants N2 and E268. These experiments showed that, in N2- and E268-infected cells, one of the virus-specified nonstructural (NS) polypeptides (NS p89; H. Brzeski and S. I. T. Kennedy, J. Virol. 22:420-429, 1977) is thermolabile after shift up to restrictive temperature. This finding, together with the observation that, after shift, the 26S/42S RNA ratio in N2-infected cells changes markedly in favor of 42S RNA synthesis, leads us to conclude that, of the three NS polypeptides, NS p89 modulates $26 \mathrm{~S}$ RNA synthesis.
\end{abstract}

The genetic material of alphaviruses, such as Sindbis virus and Semliki Forest virus (SFV), is single-stranded RNA, which has a molecular weight of $4.2 \pm 0.2 \times 10^{6}$ and a sedimentation coefficient of about $42 \mathrm{~S}(19,23)$. This RNA is infectious; i.e., it has positive polarity $(15,21)$ and is translated inside infected cells to give nonstructural (NS) polypeptides that are components of the virus-specified RNA-dependent RNA polymerase $(10,14)$. In addition to $42 \mathrm{~S}$ RNA, infected cells contain large amounts of a second virus-specified single-stranded RNA of positive polarity $(26 \mathrm{~S}$ RNA $[15,19,23]$; molecular weight, $\left.1.8 \pm 0.1 \times 10^{6}[19,23]\right)$, which acts as mRNA for the structural proteins of the virus particle $(9,12,13,25,26)$. It has recently been shown that the nucleotide sequence of 26S RNA is located inward from the $3^{\prime}$ end of the $42 \mathrm{~S}$ RNA genome $(17,28)$. Since it is clear from several studies that the template for synthesis of both 42S and 26S RNA is 42S RNA of negative polarity $(4,19,24)$, at least two possible

† Present address: Department of Biology, University of California-San Diego, La Jolla, CA 92093. mechanisms for the synthesis of 26S RNA can be envisaged. In the first, 26S RNA is synthesized by internal transcriptive initiation from a point about two-thirds of the way from the $3^{\prime}$ end of the $42 \mathrm{~S}$ negative-strand RNA template. In the second, a percentage of the newly synthesized 42S RNA molecules are processed so as to produce 26S RNA. Since no discrete RNA with a nucleotide sequence corresponding to that portion of the 42S RNA not represented in $26 \mathrm{~S}$ RNA has ever been detected $(4,24)$, generation of 26S RNA by processing of 42S RNA would involve the rapid degradation of the non-26S RNA region of newly synthesized 42S RNA. Clearly, one essential difference between these two mechanisms of synthesis of 26S RNA is the transcriptional (rather than physical) size of the negative-strand template. In the first mechanism, the transcriptional size is the same as the size of the 26S RNA; in the second mechanism, the transcriptional size is that of the entire $42 \mathrm{~S}$ negative-strand template. This difference suggested to us the use of UV irradiation of infected cells to inactivate the transcriptional template(s) 
for $42 \mathrm{~S}$ and $26 \mathrm{~S}$ RNA synthesis. From an analysis of the inactivation kinetics, we conclude not only that 26S RNA is synthesized by internal transcriptive initiation but also that there exists a single population of virus-specified RNA-synthesizing complexes whose members are each capable of synthesizing both $42 \mathrm{~S}$ and $26 \mathrm{~S}$ RNA.

To gain an insight into the role of the virusspecified nonstructural polypeptides in mediating $42 \mathrm{~S}$ and 26S RNA synthesis, we have examined the RNA and polypeptide phenotypes of several temperature-sensitive $(t s)$ mutants of Sindbis virus that synthesize less than $10 \%$ of the wild-type level of RNA when continuously incubated at restrictive temperature ( $\mathrm{RNA}^{-} \mathrm{mu}$ tants). From these studies, we tentatively conclude that one of the nonstructural polypeptides (NS p89; 7) is specifically involved in mediating 26S RNA synthesis. Finally, taking this observation together with our findings on the mechanism of transcription of 26S RNA, we present a model for the synthesis of alphavirus RNA.

\section{MATERIALS AND METHODS}

Materials. Acrylamide and sodium dodecyl sulfate (especially pure grade) were obtained from British Drug Houses Ltd., $N, N^{\prime}$-methylenebisacrylamide from Eastman Organic Chemical Div., Eastman Kodak Co., Rochester, N.Y., HEPES ( $N$-2hydroxyethyl piperazine- $N^{\prime}$-2-ethanesulfonic acid) from Flow Laboratories Ltd., and L- $\left[{ }^{35}\right.$ S $]$ methionine (350 to $500 \mathrm{Ci} / \mathrm{mmol}),\left[5-{ }^{3} \mathrm{H}\right]$ uridine $(25 \mathrm{Ci} / \mathrm{mmol})$, and $\left.{ }^{32} \mathrm{P}\right]$ orthophosphate $(89$ to $104 \mathrm{Ci} / \mathrm{mg}$ of phosphorus) from the Radiochemical Centre. Actinomycin D was a generous gift from Merck Sharp and Dohme.

Viruses and cells. The origin and the preparation of working stocks of the AR339 strain of Sindbis virus and its $t s$ mutants have been described (7). The standard SFV and its defective-interfering (DI) particles (passage 6 fluid) used in the present study were those described by Bruton and Kennedy (5). Experiments were performed using monolayer cultures of BHK (clone 13) cells or primary chicken embryo fibroblasts prepared and cultivated as described before (7).

Radioactive labeling of cells. For experiments involving labeling with $\left[{ }^{35}\right.$ S]methionine, cells seeded in methionine-depleted medium were infected, labeled with $\left.{ }^{35} \mathrm{~S}\right]$ methionine, and chased, and extracts were prepared for electrophoresis as described in detail before (7). For experiments involving labeling with $\left[{ }^{32} \mathrm{P}\right]$ orthophosphate, cells were seeded in $5-\mathrm{cm}$ plastic petri dishes $\left(9 \times 10^{6}\right.$ cells per dish) and incubated overnight in Glasgow-modified minimal essential medium containing one-tenth the normal amount of phosphate, $10 \%$ dialyzed calf serum, and $5 \mu \mathrm{Ci}$ of $\left[{ }^{3} \mathrm{H}\right]$ uridine per $\mathrm{ml}(3 \mathrm{ml}$ of medium per dish). The following morning, the monolayers were washed once with Glasgow-modified minimal essential medium containing one-tenth the normal amount of phosphate, $2 \%$ dialyzed calf serum, and $1 \mu \mathrm{g}$ of actinomycin D per ml (incubation medium) and then infected with
50 to $100 \mathrm{PFU}$ of virus per cell at $30^{\circ} \mathrm{C}$ for the $t s$ mutants and $37^{\circ} \mathrm{C}$ for wild-type virus and DI particles. After adsorption for $1 \mathrm{~h}$, the inoculum was replaced with prewarmed incubation medium, and the cultures were replaced at the appropriate temperature. Immediately before labeling, cultures were washed once with phosphate-free Earle salts solution containing $2 \%$ dialyzed calf serum, $1 \mu \mathrm{g}$ of actinomycin $\mathrm{D}$ per $\mathrm{ml}$, and $20 \mathrm{mM}$ HEPES (pH 7.4) and then incubated in this medium containing $500 \mu \mathrm{Ci}$ of $\left[{ }^{32} \mathrm{P}\right]$ orthophosphate per $\mathrm{ml}$ (labeling medium; $2 \mathrm{ml}$ per culture). The time (specified relative to the end of adsorption) and duration of labeling (both with $\left.{ }^{35} \mathrm{~S}\right]$ methionine and $\left[{ }^{32} \mathrm{P}\right]$ orthophosphate) are given in individual experiments.

UV irradiation of infected cells. Infected cultures were removed from the incubator at the time specified in individual experiments, washed three times with warmed phosphate-free Earle salts solution, drained, and irradiated at room temperature (or at $39^{\circ} \mathrm{C}$ for $t s$ mutant-infected cultures) for up to 14 min. The emission wavelength of the lamp (Anderman and Co., Ltd., London) was $256 \mathrm{~nm}$, and the dosage was $30 \mathrm{ergs} / \mathrm{s}$ per $\mathrm{mm}^{2}$. After irradiation, the cultures were incubated for $1 \mathrm{~h}$ in labeling medium (see earlier) containing $10 \mu \mathrm{g}$ of cycloheximide per ml. Cycloheximide was present to prevent further production of virus-specified RNA polymerase.

Extraction of RNA. All materials and solutions were autoclaved before use. At the end of the labeling period, the monolayers were washed three times with chilled phosphate-buffered saline lacking $\mathrm{Ca}^{2+}$ and $\mathrm{Mg}^{2+}$ and once with chilled $50 \mathrm{mM}$ Tris (pH 7.4) containing $0.1 \mathrm{M} \mathrm{NaCl}$ and $1 \mathrm{mM}$ EDTA (TNE). The cells from each dish were scraped off, collected by centrifugation at $500 \times g$ for $5 \mathrm{~min}$ at $4^{\circ} \mathrm{C}$, and resuspended in $2 \mathrm{ml}$ of TNE at room temperature. Then $0.5 \mathrm{ml}$ of $10 \%$ Triton N-101 in TNE was added, and, after $2 \mathrm{~min}$ at room temperature, nuclei were removed by centrifuging at $1,000 \times g$ for $2 \mathrm{~min}$ at $4^{\circ} \mathrm{C}$. The resultant supernatant was made $2 \%$ in sodium dodecyl sulfate and either extracted immediately or stored at $-70^{\circ} \mathrm{C}$ for up to 1 week. A total nucleic acid extract of each cytoplasmic preparation was prepared as described previously (11) and alcohol precipitated at $-20^{\circ} \mathrm{C}$ in the presence of $100 \mu \mathrm{g}$ of carrier tRNA.

Polyacrylamide gel electrophoresis. $\left[{ }^{35}\right.$ S]methionine-labeled polypeptides were analyzed by electrophoresis on $7.5 \%(\mathrm{wt} / \mathrm{vol})$ acrylamide $+0.2 \%(\mathrm{wt} / \mathrm{vol})$ $N, N^{\prime}$-methylenebisacrylamide slab gels, as described before (10). After electrophoresis (at $45 \mathrm{~V}$ for $16 \mathrm{~h}$ ), gels were dried under vacuum at $90^{\circ} \mathrm{C}$ and autoradiographed on Kodirex X-ray film. [ $\left.{ }^{32} \mathrm{P}\right]$ orthophosphatelabeled nucleic acids were analyzed as follows. Samples were centrifuged at $2,500 \times g$ for $10 \mathrm{~min}$ at $4^{\circ} \mathrm{C}$, and the pelleted nucleic acids were washed by recentrifugation in $70 \%$ ethanol containing $50 \mathrm{mM}$ $\mathrm{NaCl}$, dried in a stream of $\mathbf{N}_{2}$ gas, and dissolved in a small volume of one-fifth TNE containing $0.2 \%$ sodium dodecyl sulfate and $20 \%$ sucrose. A known quantity of each solution was counted for both tritium and [ $\left.{ }^{32} \mathrm{P}\right]$ orthophosphate, and, in comparative studies, the same number of tritium counts of each sample were applied to slots in a slab gel (20 by 18.5 by $0.15 \mathrm{~cm}$ ) consisting of $1.7 \%(\mathrm{wt} / \mathrm{vol})$ acrylamide, $0.085 \%$ 
$N, N^{\prime}$-methylenebisacrylamide, and $0.5 \%$ agarose (11). Electrophoresis was at $45 \mathrm{~V}$ for 16 to $18 \mathrm{~h}$. The gel was then dried under vacuum at $90^{\circ} \mathrm{C}$, marked with radioactive ink, and autoradiographed on Kodirex Xray film. After the autoradiograph was aligned with the dried gel, portions of the gel containing the virusspecified RNAs were cut out and counted by scintillation spectrometry.

Calculation of inactivation kinetics. UV irradiation has been shown to cause the formation of uracil dimers in mengovirus RNA (20). It has been suggested that such dimers act as a physical block and result in premature termination of transcription (16). For this reason, it was assumed that the number of templates remaining transcriptionally active after irradiation was reflected by the counts per minute of $\left[{ }^{32} \mathrm{P}\right]$ orthophosphate incorporated into the respective RNAs in the following hour. Hence, the rate of template inactivation can be expressed by the first-order equation: In (counts per minute in RNA after irradiation time $t /$ counts per minute in RNA with no irradiation) $=K_{i}$ $\times$ time of irradiation, where $K_{i}$ is the inactivation constant and provides a measure of the size of the template. In all experiments, $K_{i}$ was determined graphically by using the method of least squares. All points were given equal weighting, and only those with counts per minute greater than three times the background (determined using a piece of gel containing no RNA) were used. Preliminary experiments showed that after 15 min of irradiation (longer than used in any analysis) no small RNA fragments were detected. In addition to $K_{i}$, a second term, $t_{37 \%}$, was also determined. This term corresponds to the irradiation time at which the amount of $\left[{ }^{32} \mathrm{P}\right]$ orthophosphate incorporated into an RNA species has been reduced to $37 \%$ of its original value. The significance of this term can be envisaged as follows. Consider a large population of templates exposed to UV radiation. The probability of any single template remaining active (i.e., unhit) is given by the Poisson distribution: $\operatorname{Pr}=\left(x^{r} / r !\right) \cdot e^{-x}$, where $\operatorname{Pr}$ is the probability of the template having received $r$ hits when the average is $x$ hits per template. In the case where there has been an average of 1 hit per template, the probability that a template is unhit (i.e., $r=0$ ) is $1 / e=$ 0.3679 . Thus, at the time at which there is an average of 1 hit per template, $36.8 \%$ of the templates are still unhit and involved in RNA synthesis. This time is $t_{37 \%}$ (2).

\section{RESULTS}

UV inactivation of virus-specified RNA synthesis. To establish the efficacy of UV inactivation as a technique with which to investigate the mechanism of $42 \mathrm{~S}$ and 26S RNA synthesis, it was essential to confirm the relationship between $K_{i}$ and transcriptional size of the template. To do this, chicken fibroblasts were coinfected with standard SFV and its DI particles. We have previously shown that such cells synthesize not only $42 \mathrm{~S}$ and 26S RNA, using negative-strand 42S RNA as template, but also three size classes of DI RNA. Each of these DI RNAs contains sequences derived from the $5^{\prime}$ and $3^{\prime}$ ends of the 42S RNA genome, and each is synthesized on a negative-strand template whose transcriptional size is the same as the physical size of the progeny plus strands which it specifies (6). Thus, for these DI RNAs, a simple linear relationship should exist between $K_{i}$ and molecular weight of the DI RNAs. The inactivation profiles for the DI RNAs and for 42S and 26S RNA are shown in Fig. 1. In each case, a linear relationship was obtained between $\log _{10}$ of the percentage of RNA synthesis remaining and irradiation time. From the slopes of these lines, a value was determined for $K_{i}$ and $t_{37 \%}$ for each RNA species (Table 1). Since two of the DI RNAs, DIss1 and DIss2, have very similar molecular weights $\left(0.81 \times 10^{6}\right.$ and 0.75 $\left.\times 10^{6}[5]\right)$, the data for these two RNAs were computed together. Thus, assuming a molecular weight of $0.78 \times 10^{6}$ for DIss1/2 and taking a value for $K_{i}$ of $-0.112 \mathrm{~min}^{-1}$, the transcriptional size of the template for DIss3 can be determined from its $K_{i}$ of $-0.159 \mathrm{~min}^{-1}$ to be $1.11 \times 10^{6}$. This value is in excellent agreement with the size of DIss3 as determined by a totally unrelated technique (C. Stark and S. I. T. Kennedy, submitted for publication). For 26S RNA with a $K_{i}$ of -0.270 $\mathrm{min}^{-1}$, the size of the transcriptional template,

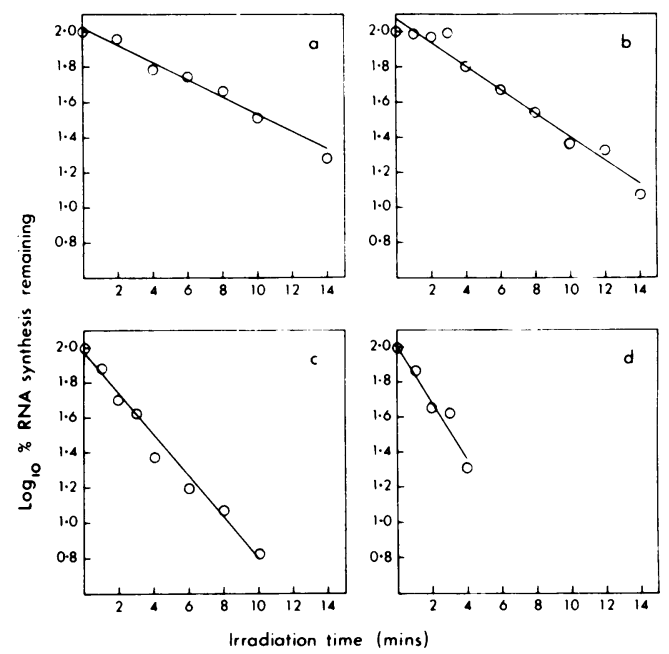

FIG. 1. UV inactivation kinetics of the synthesis of SFV RNAs. Replicate petri-dish cultures of chicken fibroblasts, prelabeled with $\left[{ }^{3} \mathrm{H}\right]$ uridine, were infected with 100 PFU of standard SFV or passage 6 fluid (4) per cell for $1 \mathrm{~h}$ at $37^{\circ} \mathrm{C}$. After removal of the inocula and incubation at $37^{\circ} \mathrm{C}$ for $4 \mathrm{~h}$, the cultures were irradiated for the times specified and then immediately incubated in ${ }^{32}$ P]orthophosphate labeling medium (see the text) containing $10 \mu \mathrm{g}$ of cycloheximide per $\mathrm{ml}$ for $1 \mathrm{~h}$. After phenol-chloroform extraction, the ${ }^{32} P$ radioactivity incorporated into $(a)$ DIss1/2, (b) DIss3, (c) 26S RNA, and (d) 42S RNA was determined by gel electrophoresis as described in the text. 
TABLE 1. UV inactivation kinetics of the synthesis of SFV RNAs

\begin{tabular}{|c|c|c|c|c|c|c|}
\hline RNA species & $\begin{array}{c}K_{i} \\
\left(\min ^{-1}\right)\end{array}$ & $\begin{array}{c}t_{37 q_{6}} \\
(\min )\end{array}$ & $\begin{array}{c}\text { Determined } \\
\text { mol wt } \\
\left(\times 10^{-6}\right)\end{array}$ & $\begin{array}{l}\text { Actual mol wt } \\
\qquad\left(\times 10^{-6}\right)\end{array}$ & $\begin{array}{c}\text { Labeling } \\
\text { 42S/26S RNA } \\
\text { ratio }^{\alpha} \\
\end{array}$ & $\begin{array}{c}\text { Molar } 42 \mathrm{~S} / 26 \mathrm{~S} \\
\text { RNA ratio }\end{array}$ \\
\hline DIss1/2 & -0.112 & 8.92 & $(0.78)^{b}$ & 0.78 & & \\
\hline DIss3 & -0.159 & 6.29 & 1.11 & 1.11 & $1: 2.84$ & 1:6.62 \\
\hline $26 \mathrm{~S}$ & -0.270 & 3.71 & 1.88 & 1.80 & & \\
\hline $42 S$ & -0.375 & 2.66 & 2.62 & 4.2 & & \\
\hline
\end{tabular}

${ }^{a}$ Calculated from the counts per minute in the respective RNA bands.

${ }^{b}$ Taking the average actual molecular weight of DIss $1 / 2$ as standard.

again calculated by using the $K_{i}$ and molecular weight of DIss1/2 as standard, was $1.88 \times 10^{6}$. This value is very close to that of the physical size of $26 \mathrm{~S}$ RNA $(19,23)$. From this experiment, it would appear, therefore, that the synthesis of 26S RNA involves internal transcriptive initiation at or close to a point two-thirds of the way from the $3^{\prime}$ end of the $42 \mathrm{~S}$ negative-strand template. For $42 \mathrm{~S}$ plus-strand RNA synthesis, the value obtained for the transcriptional size of the template in this experiment was $2.62 \times 10^{6}$. This value is considerably less than $4.2 \pm 0.2 \times 10^{6}$, the physical size of $42 \mathrm{~S}$ RNA $(19,23)$. Under the conditions used in this experiment, the molar ratio of $42 \mathrm{~S}$ to $26 \mathrm{~S}$ RNA was approximately 1:6 (Table 1); therefore, assuming equal rates of polynucleotide elongation for 42S and 26S RNA and synthesis of 26S RNA by internal transcriptive initiation, the non-26S region of a fraction of the population of templates may not be continuously transcribed. As a consequence of this, it is possible that not all UV hits in this region of the template will be manifest by a reduced synthesis of 42S RNA, because of intermittent use of the template. In other words, an apparently inaccurate (low) value for $K_{i}$ for 42S RNA $\left(K_{i 42 S}\right)$ will be obtained. To test this hypothesis, we repeated the inactivation experiment using cells infected with an $\mathrm{RNA}^{-} t s$ mutant of Sindbis virus (N2), which, after shift up from permissive to restrictive temperature, synthesizes $42 \mathrm{~S}$ and 26S RNA in an almost equimolar ratio (see later for details of the RNA phenotype of N2). For comparison with SFV-infected cells, wild-type Sindbis virus-infected cells were also irradiated. The result of this experiment is shown in Fig. 2 and Table 2. For 26S RNA, the value of $K_{i}\left(K_{i 265}\right)$ was about the same for wild-type virus-infected and N2-infected cells and similar to the $K_{i 26 S}$ for SFV-infected cells (Table 1). In addition, the values for $K_{i 42 S}$ and the 42S/26S RNA ratio for wild-type Sindbis virus-infected cells were close to those for SFV-infected cells. Thus, for cells infected with wild-type Sindbis or SFV, the apparent transcriptional size of the template for 42S RNA appears to be only about $60 \%$ of the physical size. In marked contrast, however, the transcriptional size of the template for 42S RNA

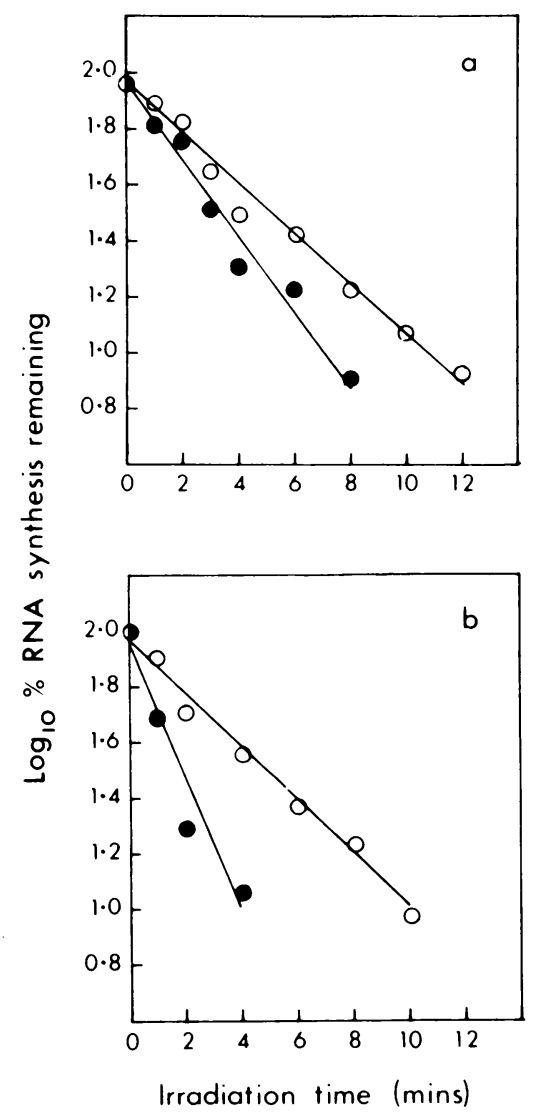

FIG. 2. UV inactivation kinetics of the synthesis of Sindbis wild-type virus and mutant N2 RNAs. Replicate petri-dish cultures of chicken fibroblasts, prelabeled with $\left[{ }^{3} \mathrm{H}\right]$ uridine, were infected with 50 to 100 PFU of wild-type Sindbis virus or mutant N2 per cell for $1 \mathrm{~h}$ at $30^{\circ} \mathrm{C}$. After removal of the inocula and incubation at $30^{\circ} \mathrm{C}$ for $5 \mathrm{~h}$, the cultures were shifted to $39^{\circ} \mathrm{C}$ for $2 \mathrm{~h}$ and then irradiated and labeled $\left(a t 39^{\circ} \mathrm{C}\right)$ as described in the legend to Fig. 1. After phenol-chloroform extraction, the radioactivity incorporated into (a) wild-type RNA $(\mathrm{O}, 26 \mathrm{~S}$; 9 , 42S) and (b) N2 RNA $(O, 26 S$;, $42 S)$ was determined by gel electrophoresis as described in the text.

in N2-infected cells was calculated from a $K_{i}$ of $-0.534 \mathrm{~min}^{-1}$ to be $4.35 \times 10^{6}$. This value agrees closely with the physical size of the template. 
TABLE 2. UV inactivation kinetics of the synthesis of Sindbis wild-type virus and mutant N2 RNAs

\begin{tabular}{|c|c|c|c|c|c|c|}
\hline RNA species & $\begin{array}{c}K_{t} \\
\left(\min ^{-1}\right)\end{array}$ & $\begin{array}{c}t_{3 i^{\prime}} \\
(\mathrm{min})\end{array}$ & $\begin{array}{c}\text { Determined } \\
\text { mol wt } \\
\left(\times 10^{-6}\right)\end{array}$ & $\begin{array}{l}\text { Actual } \\
\text { mol wt } \\
\left(\times 10^{-6}\right)\end{array}$ & $\begin{array}{c}\text { Labeling } \\
42 \mathrm{~S} / 26 \mathrm{~S} \\
\text { RNA ratio" }\end{array}$ & $\begin{array}{c}\text { Molar } \\
42 \mathrm{~S} / 26 \mathrm{~S} \\
\text { RNA ratio }\end{array}$ \\
\hline Wild-type $26 \mathrm{~S}$ & -0.206 & 4.85 & $(1.8)^{b}$ & 1.8 & \multirow{2}{*}{$1: 2.30$} & \multirow{2}{*}{ 1:5.37 } \\
\hline Wild-type $42 \mathrm{~S}$ & -0.315 & 3.18 & 2.74 & 4.2 & & \\
\hline Mutant N2 26S & -0.221 & 4.52 & $(1.8)^{b}$ & 1.8 & \multirow[t]{2}{*}{$1: 0.62$} & \multirow[t]{2}{*}{$1: 1.43$} \\
\hline Mutant N2 42S & -0.534 & 1.87 & 4.35 & 4.2 & & \\
\hline
\end{tabular}

" Calculated from the counts per minute in the respective RNA bands.

${ }^{\circ}$ Taking the actual molecular weight of 26S RNA as standard.

Thus, under conditions of $42 \mathrm{~S}$ and $26 \mathrm{~S}$ RNA synthesis in a molar ratio of $1: 1.43$, where perhaps little or no redundancy exists in transcription of the non-26S RNA region of the template, the transcriptional size (as measured by UV inactivation kinetics) and physical size of the template for $42 \mathrm{~S}$ RNA synthesis are the same. The significance of this possible redundancy in the non-26S RNA region of the template will be discussed later.

RNA and polypeptide phenotypes of Sindbis virus $\mathrm{RNA}^{-}$ts mutants. Of the 75 $\mathrm{RNA}^{-} t s$ mutants originally isolated by Atkins et al. (1), 15 were chosen at random, and their RNA and polypeptide phenotypes were analyzed. For RNA phenotype analysis, duplicate cultures of BHK cells were infected with wildtype virus or the $t s$ mutants and then incubated at $30^{\circ} \mathrm{C}$ for $6.5 \mathrm{~h}$ to allow virus-specified RNA synthesis to become established. At this time, one of each duplicate culture was shifted to $39^{\circ} \mathrm{C}$, and all cultures were labeled from 7.5 to $8 \mathrm{~h}$ postinfection. Analysis of the ratio of $42 \mathrm{~S}$ to 26S RNA synthesized at both temperatures during the 30 -min pulse is shown in Fig. 3 as a histogram. At $30^{\circ} \mathrm{C}$, the RNA ratio ranged from 0.2 to 0.9 , with 10 of the mutants examined giving a ratio within 0.1 of that obtained with wild-type virus. By contrast, the RNA ratio for most of the mutants after shift up to restrictive temperature increased in favor of 42S RNA synthesis, and for three mutants (N2, N7, and E268) this increase was marked. Since it is well established that late in the alphavirus multiplication cycle (by $3.5 \mathrm{~h}$ postinfection for wild-type virus at $30^{\circ} \mathrm{C}$, and 3.5 to $6.75 \mathrm{~h}$ postinfection for the $\mathrm{RNA}^{-}$mutants at $30^{\circ} \mathrm{C}$ ) the overall rate of virusspecified RNA synthesis is constant (4) and independent of continued virus-specified protein synthesis $(21,27)$, we decided to examine in more detail the altered RNA phenotype for mutant $\mathrm{N} 2$ after shift up to $39^{\circ} \mathrm{C}$. Accordingly, cells infected with wild-type virus or N2 were incu- bated at $30^{\circ} \mathrm{C}$ until $6 \mathrm{~h}$ postinfection and then shifted to $39^{\circ} \mathrm{C}$ and labeled from 6 to $6.5,7$ to 7.5 , and 8 to $8.5 \mathrm{~h}$ postinfection. Quantitation of the label incorporated into $42 \mathrm{~S}$ and $26 \mathrm{~S} \mathrm{RNA}$ during each pulse period is shown in Fig. 4. Clearly, for N2, there was little overall change in the extent of virus-specified RNA synthesis after shift up; rather, there was a gradual reduction in 26S RNA synthesis and a concomitant increase in the synthesis of 42S RNA. Under identical shift-up conditions there was no measurable effect of incubation at $39^{\circ} \mathrm{C}$ on the $42 \mathrm{~S} / 26 \mathrm{~S}$ RNA ratio in wild-type-infected cells. The gradual nature of the change in the $42 \mathrm{~S} / 26 \mathrm{~S}$ RNA ratio in N2-infected cells after shift up suggested some alteration in the function of one or more of the virus-specified polypeptide components of the polymerase $(3,21)$. To investigate this, we examined the polypeptide phenotype of cells infected with mutant $\mathrm{N} 2$, using a protocol similar to that employed in examining the RNA phenotype. The results of this experiment are shown in Fig. 5. After a 15 -min pulse at $30^{\circ} \mathrm{C}$, followed by a $1-\mathrm{h}$ chase at the same temperature at $6.5 \mathrm{~h}$ postinfection (Fig. 5, lane a), all of the NS polypeptides (NS p89, NS p60, and $p 76$, the immediate precursor to NS p82 [7]), the putative components of the virus-specified polymerase, were clearly visible. In addition, p150, the precursor to NS p89 and NS p60 (7), was detected. However, after shift up to $39^{\circ} \mathrm{C}$ at $6 \mathrm{~h}$ postinfection, pulsing at $39^{\circ} \mathrm{C}$, and then chasing at $30^{\circ} \mathrm{C}$ (lane b) or $39^{\circ} \mathrm{C}$ (lane c) at $7 \mathrm{~h}$ postinfection, the NS polypeptides were barely detectable, and p215, which contains the amino acid sequence of NS p89, p76, and NS p60 (7), was formed. Thus, the genetic lesion in N2 is manifest not only by an alteration in the $42 \mathrm{~S} / 26 \mathrm{~S}$ RNA ratio but also by failure to cleave p215. A similar defect has recently been described for one of the HR mutants of Sindbis virus (3) originally isolated by Burge and Pfefferkorn (8). Since we have previously shown that the $\mathrm{N}$ terminal-to- 


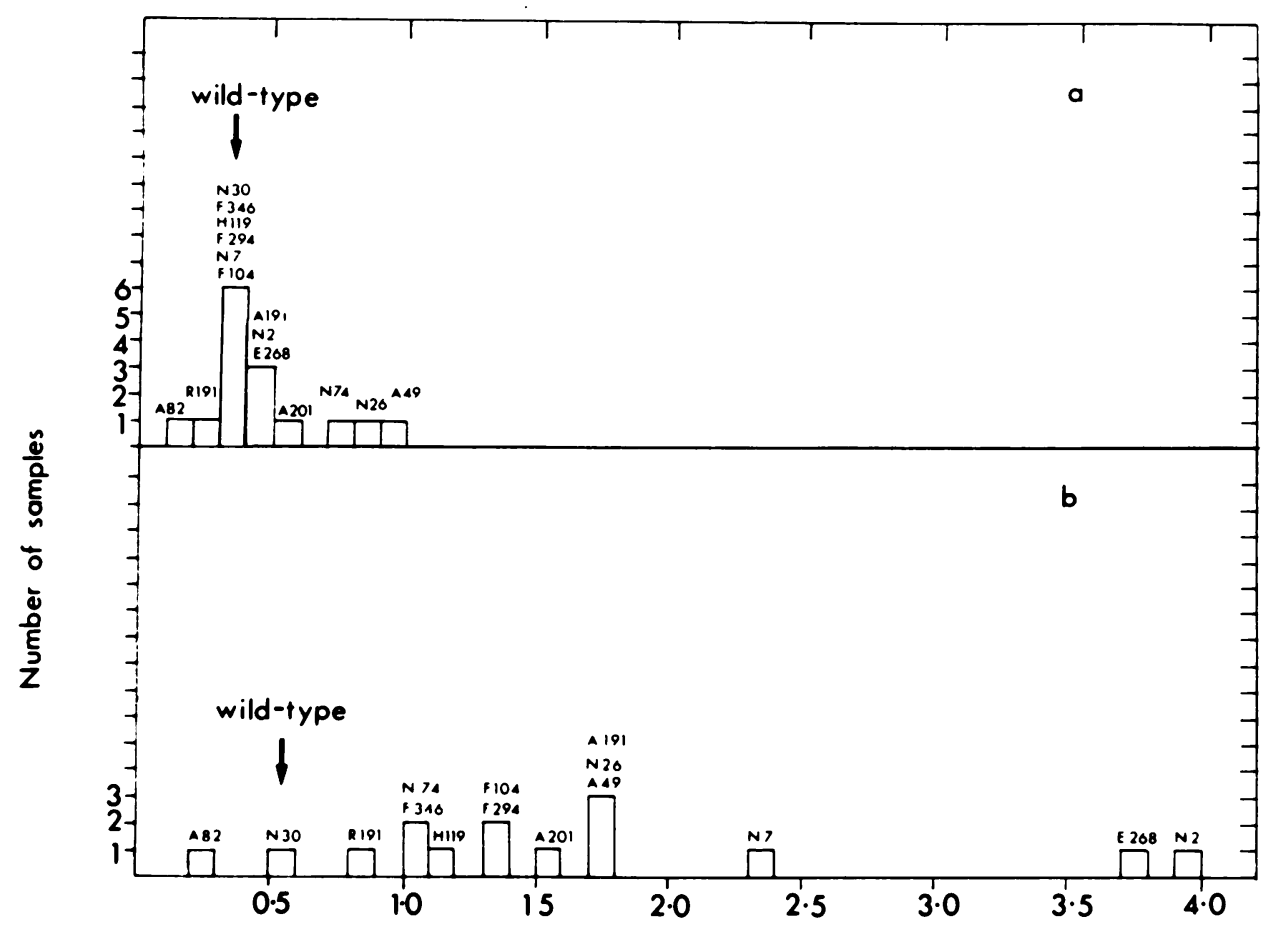

\section{Ratio of 42S: 26S RNA species}

Fig. 3. Ratio of $42 S$ to $26 S$ RNA in cells infected with wild-type virus and $R N A^{-}$mutants. Pairs of cultures were infected for $1 \mathrm{~h}$ at $4^{\circ} \mathrm{C}$ with 30 to $75 \mathrm{PFU}$ of wild-type virus or the $\mathrm{RNA}^{-}$mutants per cell. After removal of inocula, the cultures were incubated at $30^{\circ} \mathrm{C}$ until $6 \mathrm{~h}$ postinfection, when one of each pair of cultures was shifted to $39^{\circ} \mathrm{C}$. At $7.5 \mathrm{~h}$ postinfection, all cultures were labeled at their respective temperature with [ ${ }^{32}$ P]orthophosphate for $30 \mathrm{~min}$. RNA was extracted, and the ratio of radioactivity incorporated into $42 \mathrm{~S}$ and $26 \mathrm{~S} \mathrm{RNA}$ at $30^{\circ} \mathrm{C}(\mathrm{a})$ and $39^{\circ} \mathrm{C}$ (b) was determined by polyacrylamide gel electrophoresis as described in the text.

C terminal order of the NS polypeptides in p215 is NS p60-NS p89-NS p82 and that the first cleavage of p215 removes p76 (the immediate precursor to NS p82 [7]), it would seem probable that the ts lesion in mutant N2 lies in the gene coding for either NS p89 or NS p82, the two polypeptides adjacent to the cleavage points, and that failure to perform this cleavage results in cessation of formation of any of the NS polypeptides. Taking the RNA and polypeptide phenotype data for mutant N2 together, it is tempting to conclude that it is failure to continue synthesis of the NS polypeptides that results in increased synthesis of 42S RNA at the expense of 26S RNA. However, this failure in synthesis is not by itself sufficient to account for the altered RNA ratio, since, by $6 \mathrm{~h}$ postinfection, there exists a pool of previously synthesized NS polypeptides which, if functionally stable, should maintain the wild-type RNA ratio in N2-infected cells even after shift up. Since this is clearly not the case (Fig. 4), it would appear that one of the NS polypeptides, probably either NS p89 or NS p82, undergoes a temperaturemediated conformational change on shift up to restrictive temperature and that this change results in an altered RNA ratio. Thus, it is not failure to continue synthesis of the NS polypeptides at restrictive temperature per se that results in an altered RNA ratio, but rather that the lesion, although manifest in cleavage failure, also results in an altered function of one of the NS polypeptides at the restrictive temperature.

Stability of the NS polypeptides in mutant-infected cells: It has recently been reported for vesicular stomatitis virus that mutant virus-specified polypeptides are more rapidly degraded at restrictive temperature than the respective wild-type polypeptide (18). To investigate whether a similar situation pertained for any of the NS polypeptides in mutant N2-infected cells, chicken fibroblasts were infected 


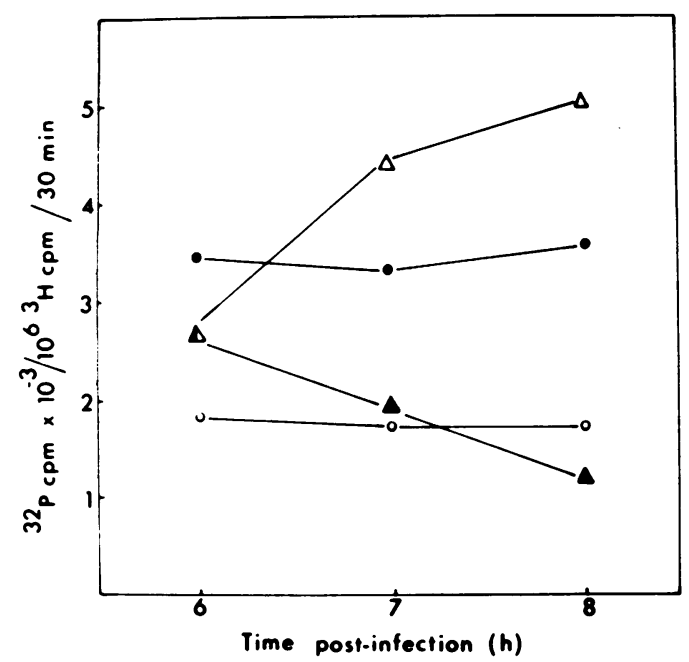

FIG. 4. Synthesis of $42 S$ and $26 S$ RNA in cells infected with wild-type Sindbis virus and mutant N2 after shift up to restrictive temperature. Two sets of three cultures of chicken fibroblasts, prelabeled with $\left[{ }^{3} \mathrm{H}\right]$ uridine, were infected for $1 \mathrm{~h}$ at $4^{\circ} \mathrm{C}$ with 50 to 75 PFU of either wild-type Sindbis virus or mutant N2 per cell. After removal of the inocula, the cultures were incubated at $30^{\circ} \mathrm{C}$ for $6 \mathrm{~h}$ and then shifted to $39^{\circ} \mathrm{C}$. One of each type of culture was then labeled with ${ }^{32}$ P]orthophosphate from 6 to $6.5,7$ to 7.5, and 8 to $8.5 \mathrm{~h}$ postinfection, respectively, and after extraction the radioactivity from wild-type-infected cells in (O) 42S RNA and (O) 26S RNA, and from N2-infected cells in $(\triangle)$ 42S RNA and ( $\triangle$ ) 26SRNA, was determined by gel electrophoresis as described in the text.

with either N2 or wild-type virus and, after incubation at permissive temperature for $5.5 \mathrm{~h}$, were labeled for $30 \mathrm{~min}$, chased for $30 \mathrm{~min}$ to allow formation of the NS polypeptides, and then shifted to restrictive temperature, and the polypeptide profile was analyzed after various times (Fig. 6). For the wild type, the NS polypeptides were stable throughout incubation at $39^{\circ} \mathrm{C}$ (Fig. 6, lanes a to c). In cells infected with N2 (lanes d to f), NS p60 and NS p82 (p76) were stable, but NS p89 was rapidly degraded. (Note that, during prolonged chase, p76 is converted to NS p82 [7].) In a modification of this experiment, cultures infected with $\mathrm{N} 2$ were returned to $30^{\circ} \mathrm{C}$ for $2 \mathrm{~h}$ after $3 \mathrm{~h}$ of incubation at $39^{\circ} \mathrm{C}$, and their polypeptide profile was examined (data not presented). Under these conditions, NS p82 and NS p60 were visible, but NS p89 was not detectable. Thus it seems likely that NS p89 in N2-infected cells at $39^{\circ} \mathrm{C}$ is in fact degraded and not simply reversibly modified so as to change its electrophoretic mobility. Since mutant E268, like mutant N2, also showed a marked change in the $42 \mathrm{~S} / 26 \mathrm{~S}$ RNA ratio at restrictive temperature (Fig. 3), it was of interest to determine whether NS p89 was unstable at $39^{\circ} \mathrm{C}$ in E268-infected cells. The result of an experiment to investigate this is shown in Fig. 7. In E268-infected cells, no p215 was detectable under any conditions, and the NS polypeptides were produced both at $30^{\circ} \mathrm{C}$ (Fig. 7, lane a) and $39^{\circ} \mathrm{C}$ (lane c). Thus, in cells infected with mutant E268, unlike those infected with mutant N2 (Fig. 5), processing of the NS polypeptide precursors occurs normally both at permissive and restrictive temperatures. However, whereas NS p60 and p76 (NS p82) were stable after chasing at both temperatures, NS p89 was partially unsta-

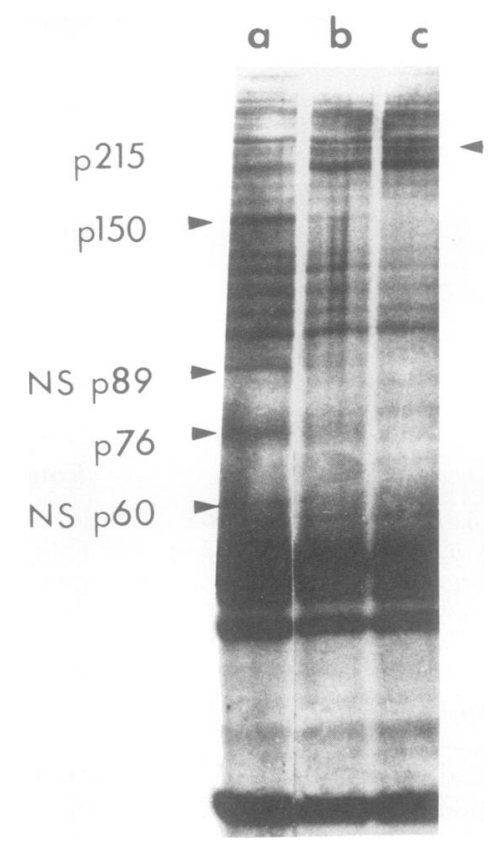

Fig. 5. Polypeptides synthesized in cells infected with mutant N2. Three cultures of chicken fibroblasts were infected for $1 \mathrm{~h}$ at $4^{\circ} \mathrm{C}$ with 50 to $75 \mathrm{PFU}$ of mutant N2 per cell. After removal of the inoculum, the cultures were incubated at $30^{\circ} \mathrm{C}$ for $6 \mathrm{~h}$, and then two of them were shifted to $39^{\circ} \mathrm{C} ; 30 \mathrm{~min}$ later, all three cultures were labeled with $50 \mu \mathrm{Ci}$ of $\left[{ }^{35} \mathrm{~S}\right]$ methionine per $\mathrm{ml}$ for $15 \mathrm{~min}$ (7). At the end of the labeling period, chase medium (7) was added, and one culture was immediately shifted down from 39 to $30^{\circ} \mathrm{C}$. After an additional $1 \mathrm{~h}$ at the respective temperature, labeled polypeptides were extracted and analyzed by polyacrylamide gel electrophoresis. Polypeptides labeled at $30^{\circ} \mathrm{C}$ and chased at $30^{\circ} \mathrm{C}$ are shown in lane $a$, those labeled at $39^{\circ} \mathrm{C}$ and chased at $30^{\circ} \mathrm{C}$ are shown in lane $b$, and those labeled at $39^{\circ} \mathrm{C}$ and chased at $39^{\circ} \mathrm{C}$ are shown in lane c. In this, as in all subsequent electrophoretograms, approximately equal quantities (40 to $50 \mathrm{\mu g}$ ) of each extract were analyzed, and migration is from top to bottom. 


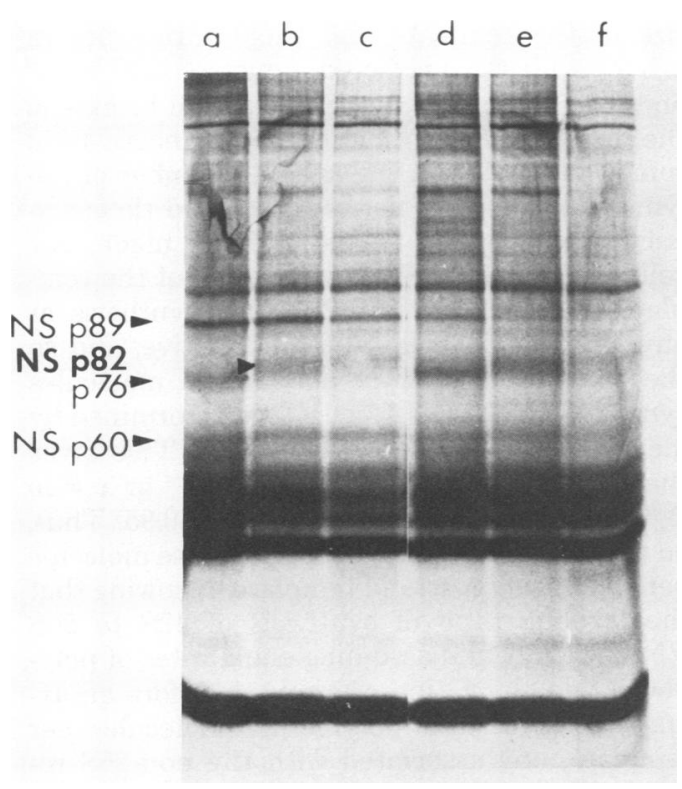

FIG. 6. Stability of the NS polypeptides in cells infected with wild-type virus and mutant N2. Two sets of three cultures of chicken fibroblasts were infected for $1 \mathrm{~h}$ at $4^{\circ} \mathrm{C}$ with 50 to $75 \mathrm{PFU}$ of either wild-type Sindbis or mutant N2 per cell. After removal of the inocula, the cultures were incubated at $30^{\circ} \mathrm{C}$ for $5.5 \mathrm{~h}$, after which all the cultures were labeled for $30 \mathrm{~min}$ at $30^{\circ} \mathrm{C}$ and then chased (7) for $30 \mathrm{~min}$ at $30^{\circ} \mathrm{C}$ before being shifted up to $39^{\circ} \mathrm{C}$. One wild-type-infected and one mutant N2-infected culture were then harvested immediately (lanes $a$ and $d$, respectively), after $1 \mathrm{~h}$ (lanes $b$ and $e$, respectively), and after $3 \mathrm{~h}$ (lanes $c$ and $f$, respectively) at $39^{\circ} \mathrm{C}$, and the labeled polypeptides were analyzed by poly. acrylamide gel electrophoresis.

ble after formation at $30^{\circ} \mathrm{C}$ and chasing at $39^{\circ} \mathrm{C}$ (lane b) and totally unstable after formation and chasing at $39^{\circ} \mathrm{C}$ (lane d). Taking these thermolability studies together, it is clear that it is not failure to maintain NS polypeptide synthesis that causes a change in the RNA ratio, but rather that the change in the RNA phenotype is due to the instability and consequent degradation of NS p89.

\section{DISCUSSION}

From the analysis of the kinetics of UV inactivation of 26S RNA synthesis in cells coinfected with standard and DI SFV (Fig. 1, Table 1), it seems clear that the mechanism of synthesis of 26S RNA from the 42S negative-strand RNA template is by internal initiation from a point about two-thirds of the way from the $3^{\prime}$ end of the template. Certainly the data are not compatible with synthesis of $26 \mathrm{~S}$ RNA by processing of a proportion of the population of newly syn- thesized 42S RNA molecules, since in this case the transcriptional size of the template for $42 \mathrm{~S}$ and 26S RNA would be the same. The conclusion that the transcriptional size of the template for 26S RNA synthesis is the same as the physical size of 26S RNA confirms the outline of the model proposed by Simmons and Strauss (24) based on hybridization data and the kinetics of labeling of Sindbis virus replicative forms. However, neither we nor others can exclude the possibility that initiation of synthesis of both $42 \mathrm{~S}$ and $26 \mathrm{~S}$ RNA occurs at the $3^{\prime}$ end of the

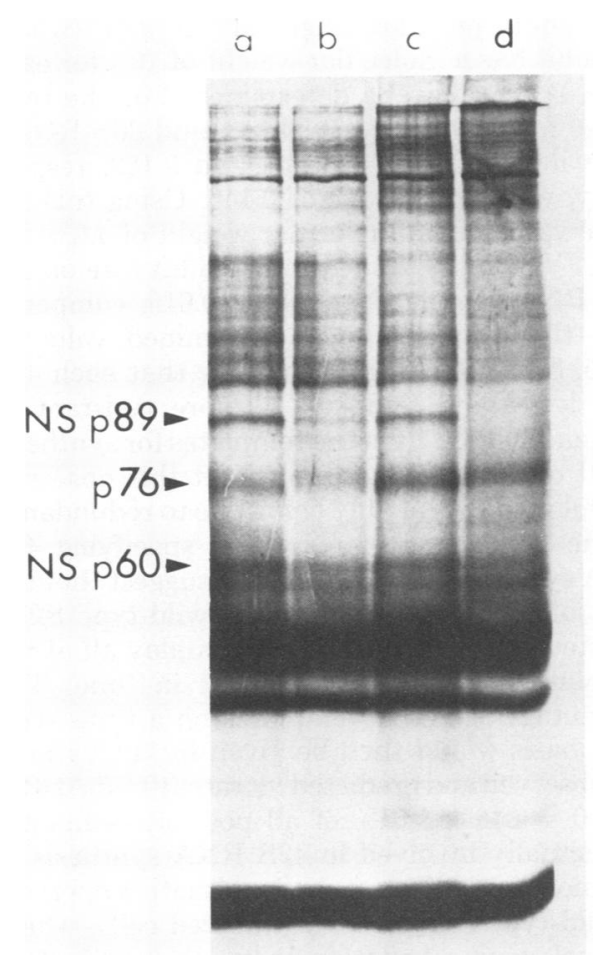

Fig. 7. Stability of the NS polypeptides in cells infected with mutant E268. Four cultures of chicken fibroblasts were infected for $1 \mathrm{~h}$ at $4^{\circ} \mathrm{C}$ with $60 \mathrm{PFU}$ of mutant E268 per cell. After removal of the inoculum, the cultures were incubated at $30^{\circ} \mathrm{C}$ for $6 \mathrm{~h}$, and then two of them were shifted up to $39^{\circ} \mathrm{C} ; 30 \mathrm{~min}$ later, all four cultures were labeled with $50 \mu \mathrm{Ci}$ of ${ }^{35} \mathrm{~S} / \mathrm{methionine}$ per $\mathrm{ml}$ for $15 \mathrm{~min}$. At the end of the labeling period, chase medium (7) was added to all the cultures, one of the $30^{\circ} \mathrm{C}$ cultures was shifted to $39^{\circ} \mathrm{C}$, and one of the $39^{\circ} \mathrm{C}$ cultures was shifted to $30^{\circ} \mathrm{C}$. After a further $1 \mathrm{~h}$, labeled polypeptides were extracted and analyzed by polyacrylamide gel elec trophoresis. Polypeptides labeled at $30^{\circ} \mathrm{C}$ and chased at $30^{\circ} \mathrm{C}$ are shown in lane a, those labeled at $30^{\circ} \mathrm{C}$ and chased at $39^{\circ} \mathrm{C}$ are shown in lane $b$, those labeled at $39^{\circ} \mathrm{C}$ and chased at $30^{\circ} \mathrm{C}$ are shown in lane $\mathrm{c}$, and those labeled at $39^{\circ} \mathrm{C}$ and chased at $39^{\circ} \mathrm{C}$ are shown in lane $d$. 
template and that in the case of $26 \mathrm{~S}$ synthesis the polymerase leaves the template shortly after initiation and reassociates with it at or near a point two-thirds of the way from the $3^{\prime}$ end. Such a possibility could be investigated by determining the nucleotide sequences at the $5^{\prime}$ end of $42 \mathrm{~S}$ and $26 \mathrm{~S}$ RNA.

From the inactivation kinetics (Tables 1 and 2 ), a value for $t_{37 \%}$ for each RNA species was determined. Each of these values corresponds to the irradiation time required to produce, on average, one hit per template (see above for details). From these values, the number of hits per minute per unit length of template (where one unit has a molecular weight of $10^{6}$ ) for each RNA species can be determined. For the templates for SFV DIss1/2, DIss3, and 26S RNAs, the values are $0.144,0.145$, and 0.150 , respectively, with an average of 0.146 . Using this average value and a molecular weight of $4.2 \times 10^{6}$ for SFV 42S RNA, the predicted hit rate on the 42S RNA template would be 0.615 , compared with the experimentally determined value of 0.375 . Since it is highly unlikely that each $42 \mathrm{~S}$ negative-strand template is more resistant to UV inactivation than the templates for synthesis of DI or 26S RNA, we interpret this observed low hit rate as probably being due to redundancy in the population of templates specifying $42 \mathrm{~S}$ RNA synthesis. Specifically, we suggest that the level of 42S RNA synthesis in wild-type SFVinfected cells is insufficient to employ all of the template RNAs at any instant in time. The percentage of active templates on a time-averaged basis would then be given by the ratio of the observed and predicted hit rates $(0.375 / 0.615)$ $\times 100=61$; i.e., $61 \%$ of all possible templates are actually involved in 42S RNA synthesis at any moment in time. A similar situation operates in wild-type Sindbis virus-infected cells, where an analogous calculation shows that $66 \%$ of all templates are in use at any moment. This contrasts with cells infected with mutant N2 which, after shift up to restrictive temperature, synthesize four times as much 42S RNA (relative to 26S RNA) as wild-type-infected cells, and where the experimentally determined transcriptional size of the template and the hit rate are in accord with the predicted values of $4.35 \times 10^{6}$ and 0.623 , respectively. It is possible to extend the analysis of the kinetics of UV inactivation somewhat to obtain the average number of polymerase molecules per template and their distribution in terms of types of RNA made. For cells infected with SFV, where $61 \%$ of the templates are involved in 42S RNA synthesis at any moment in time, $39 \%$ are inactive, and so the average number of polymerase molecules synthesizing 42S RNA $(x)$ can be determined by means of the Poisson distribution. This gives the relationship $39 / 100=\left(x^{0} / o !\right) \cdot e^{-x}$ or $x=\ln$ $(1 / 0.39)$. This gives a value for $x$ of 0.95 . Thus, on the average there is one polymerase molecule per 42S negative-strand template. Knowing that the labeling ratio of synthesis of $42 \mathrm{~S}$ to $26 \mathrm{~S}$ RNA is 1:2.83 and assuming equal rates of polynucleotide elongation, there is therefore an average total of four polymerase molecules per template, one associated with the non- $26 \mathrm{~S}$ region and the other three with the $26 \mathrm{~S}$ region of the template. This value is somewhat less than a previous estimate determined in an entirely unrelated manner (19).

Taking all the inactivation data together with the observation that an increase in 42S RNA synthesis is balanced by a drop in 26S RNA synthesis (Fig. 4), we propose the model represented diagrammatically in Fig. 8 for the synthesis of alphavirus plus-strand RNA. We propose that there exist a number of replication complexes, each consisting of a strand of 42S RNA of negative polarity (template strand) and each having associated with it, on average, four polymerase molecules. We envisage that each of these complexes can be used for both $42 \mathrm{~S}$ and $26 \mathrm{~S}$ plus-strand synthesis, either singly or concurrently, subject only to constraints on initiation. This is in contrast to the suggestion that there exist two classes of complex, one generating 26S RNA and the other 42S RNA (22). In wild-type virus-infected cells, at least three of the four polymerase molecules are engaged in transcribing the 26S region of the template (forms $\mathrm{i}$ and ii), whereas in cells infected with

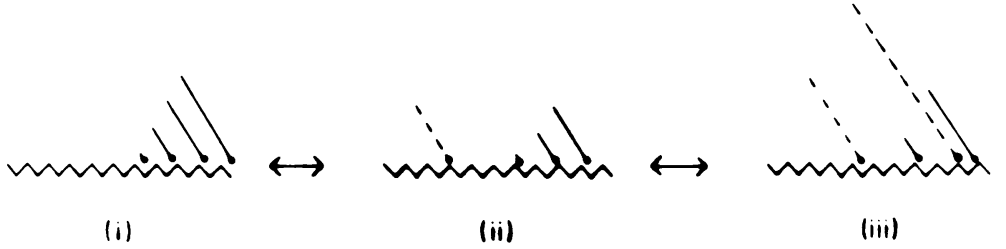

Fig. 8. Diagrammatic representation of the plus-strand RNA-synthesizing complexes in cells infected with wild-type alphaviruses. (m) $42 S$ negative-strand template RNA; (O) polymerase molecule; $(-)$ nascent 26S RNA molecule; (.....) nascent 42S RNA molecule. Form ii is the time-averaged state. 
mutants of the N2 class, where approximately equimolar synthesis of $42 \mathrm{~S}$ and $26 \mathrm{~S}$ RNA occurs after shift up to restrictive temperature, about two polymerase molecules are engaged in $42 \mathrm{~S}$ RNA synthesis and two in 26S RNA synthesis (form iii). Clearly it is possible to envisage intermediate states between wild-type-infected cells and cells infected with mutant N2. Some of the other RNA ${ }^{-}$mutants (Fig. 3) may exemplify these intermediate states.

Finally, consideration has to be given to the mechanism that controls 42S and 26S RNA synthesis. The analysis of the RNA phenotype of the $\mathrm{RNA}^{-}$mutants (Fig. 3) suggests that mutants N2, N7, and E268 have a lesion in the gene that governs 26S RNA synthesis. In marked contrast to this finding, neither we (Fig. 3) nor other workers have identified a single mutant defective in 42S RNA synthesis, i.e., a mutant able to make 26S but not 42S RNA at restrictive temperature. These observations suggest to us that synthesis of both 42S and 26S RNA is mediated not by two distinct polymerases (since in this case mutants defective in 42S RNA synthesis should exist), but rather by a single type of polymerase consisting of a core (catalytic) component required for both $42 \mathrm{~S}$ and 26S RNA synthesis together with an additional (regulatory) component which directs the core component to synthesize 26S RNA. From our studies on the mechanism of 26S RNA synthesis, we propose that regulation occurs at the level of initiation of RNA synthesis. This model would then account for the observed RNA phenotypes, since a defect in the core component would result in failure to synthesize any viral RNA, and a defect in the regulatory component would result in failure to synthesize 26S RNA, and thus only 42S RNA would be made. The decrease in 26S RNA synthesis, with the matching increase in synthesis of 42S RNA in cells infected with mutant N2 and shifted up to restrictive temperature (Fig. 4), also supports the model. Thermolability studies in cells infected with mutants N2 and E268 show that of the three NS polypeptides only NS p89 is degraded after shift up to restrictive temperature. The striking correlation between this thermolability and the change in the 42S/26S RNA ratio in favor of 42S RNA synthesis strongly suggests that NS p89 may be the regulatory component of the polymerase. The other two NS polypeptides, NS p82 and NS p60, which, together with NS p89, have been shown to be present in highly purified, enzymatically active polymerase preparations $(7,14)$, may form part of the core component. However, until it becomes possible to study the synthesis of alphavirus RNA in cell- free systems by using reconstituted polymerase components, the above concept of the structure of the polymerase must remain speculative.

\section{ACKNOWLEDGMENTS}

We thank Chris Clegg for helpful discussion and criticism. ship.

.B. is the recipient of a Medical Research Council scholar-

\section{LTERATURE CITED}

1. Atkins, G. J., J. Samuels, and S. I. T. Kennedy. 1974. Isolation and preliminary characteristics of temperature-sensitive mutants of Sindbis virus strain AR339. J. Gen. Virol. 25:371-380.

2. Ball, L. A. 1977. Transcriptional mapping of vesicular stomatitis virus in vivo. J. Virol. 21:411-414.

3. Bracha, M., A. Leone, and M. J. Schlesinger. 1976. Formation of a Sindbis virus nonstructural protein and its relation to $42 S$ mRNA function. J. Virol. 20:612-620.

4. Bruton, C. J., and S. I. T. Kennedy. 1975. Semliki Forest virus intracellular RNA: properties of the multistranded RNAs species and kinetics of positive and negative strand synthesis. J. Gen. Virol. 28:111-127.

5. Bruton, C. J., and S. I. T. Kennedy. 1976. Defectiveinterfering particles of Semliki Forest virus: structural differences between standard virus and defective-interfering particles. J. Gen. Virol. 31:383-395.

6. Bruton, C. J., A. Porter, and S. I. T. Kennedy. 1976. Defective-interfering particles of Semliki Forest virus: intracellular events during interference. J. Gen. Virol. 31:397-416.

7. Brzeski, H., and S. I. T. Kennedy. 1977. Synthesis of Sindbis virus nonstructural polypeptides in chicken embryo fibroblasts. J. Virol. 22:420-429.

8. Burge, B. W., and E. R. Pfefferkorn. 1966. Isolation and characterization of conditional-lethal mutants of Sindbis virus. Virology 30:204-312.

9. Cancedda, R., R. Swanson, and M. J. Schlesinger. 1974. Effects of different RNAs and components of the cell-free system on in vitro synthesis of Sindbis viral proteins. J. Virol. 14:652-663.

10. Clegg, J. C. S., H. Brzeski, and S. I. T. Kennedy. 1976. RNA polymerase components in Semliki Forest virus infected cells: synthesis from large precursors. J. Gen. Virol. 32:413-430.

11. Clegg, J. C. S., and S. I. T. Kennedy. 1974. Polyadenylic acid sequences in the virus RNA species of cells infected with Semliki Forest virus. J. Gen. Virol. 22:331-345.

12. Clegg, J. C. S., and S. I. T. Kennedy. 1974. In vitro synthesis of structural proteins of Semliki Forest virus directed by isolated 26S RNA from infected cells. FEBS Lett. 42:327-330.

13. Clegg, J. C. S., and S. I. T. Kennedy. 1975. Translation of Semliki Forest virus intracellular 26S RNA: characterization of the products synthesized in vitro. Eur. J. Biochem. 53:175-183.

14. Clewley, J. P. C., and S. I. T. Kennedy. 1976. Purification and polypeptide composition of Semliki Forest virus RNA polymerase. J. Gen. Virol. 32:395-411.

15. Friedman, R. M., H. B. Levy, and W. B. Carter. 1966. Replication of Semliki Forest virus: three forms of viral RNA produced during infection. Proc. Natl. Acad. Sci. U.S.A. 56:440-446.

16. Hackett, P. B., and W. Sauerbier. 1975. The transcriptional organization of the ribosomal RNA genes in mouse L cells. J. Mol. Biol. 91:235-256.

17. Kennedy, S. I. T. 1976. Sequence relationships between the genome and the intracellular RNA species of standard and defective-interfering Semliki Forest virus. J. Mol. Biol. 108:491-512. 
18. Knipe, D., H. F. Lodish, and D. Baltimore. 1977. Analysis of the defects of temperature-sensitive mutants of vesicular stomatitis virus: intracellular degradation of specific viral proteins. J. Virol. 21:1140-1148.

19. Martin, B. A. B., and D. C. Burke. 1974. The replication of Semliki Forest virus. J. Gen. Virol. 24:45-66.

20. Miller, R. L., and P. G. W. Plagemann. 1974. Effect of ultraviolet light on mengovirus: formation of uracil dimers, instability and degradation of capsid, and covalent linkage of protein to viral RNA. J. Virol. 13:729-739.

21. Scheele, C. M., and E. R. Pfefferkorn. 1969. Inhibition of interjacent ribonucleic acid (26S) synthesis in cells infected with Sindbis virus. J. Virol. 4:117-122.

22. Segal, S., and T. Sreevalsan. 1974. Sindbis virus replicative intermediates: purification and characterization. Virology 59:428-442.

23. Simmons, D. T., and J. H. Strauss. 1972: Replication of Sindbis virus. I. Relative size and genetic content of
26S and 49S RNA. J. Mol. Biol. 71:599-613.

24. Simmons, D. T., and J. H. Strauss. 1972. Replication of Sindbis virus. II. Multiple forms of double-stranded RNA isolated from infected cells. J. Mol. Biol. 71:615-631.

25. Simmons, D. T., and J. H. Strauss. 1974. Translation of Sindbis virus 26S RNA and 49S RNA in lysates of rabbit reticulocytes. J. Mol. Biol. 56:397-409.

26. Wengler, G., M. Beato, and S. A. Hackemack. 1974. Translation of $26 \mathrm{~S}$ virus-specific RNA for Semliki Forest virus-infected cells in vitro. Virology 61:120-128.

27. Wengler, G., and G. Wengler. 1975. Studies on the synthesis of viral RNA-polymerase-template complexes in BHK 21 cells infected with Semliki Forest virus. Virology 66:322-326.

28. Wengler, G., and G. Wengler. 1976. Localization of the 26S RNA sequence on the viral genome type 42S RNA isolated from SFV-infected cells. Virology 73:190-199. 